\title{
Distribution and Assessment of Heavy Metal Levels Using Geoaccumulation Index and Pollution Load Index in Lake Edku Sediments, Egypt
}

\author{
Yousef Ahmed Annaas Waheshi ${ }^{1}$, Maie Ibrahim El-Gammal ${ }^{2}$, Mahmoud Salem Ibrahim ${ }^{2}$, \\ Mohamed Abdel Aziz Okbah ${ }^{3}$ \\ ${ }^{1}$ High Institute in Jerpoly Area, Tripoli, Libya \\ ${ }^{2}$ Environmental Science Department, Faculty of Science, Damietta University, Damietta, Egypt \\ ${ }^{3}$ National Institute of Oceanography \& Fisheries, Kayet Bay, Alexandria, Egypt
}

Email address:

yousef.waheshi@gmail.com (Y. A. A. Waheshi),mgammal147@du.edu.eg (M. I. El-Gammal), mahmoudsalem1912@gmail.com (M. S. Ibrahim),m_okbah@yahoo.com (M. A. A. Okbah)

\section{To cite this article:}

Yousef Ahmed Annaas Waheshi, Maie Ibrahim El-Gammal, Mahmoud Salem Ibrahim, Mohamed Abdel Aziz Okbah. Distribution and Assessment of Heavy Metal Levels Using Geoaccumulation Index and Pollution Load Index in Lake Edku Sediments, Egypt. International Journal of Environmental Monitoring and Analysis. Vol. 5, No. 1, 2017, pp. 1-8. doi: 10.11648/j.ijema.20170501.11

Received: January 5, 2017; Accepted: January 16, 2017; Published: February 16, 2017

\begin{abstract}
The aim of this study is to determine and assessment of some heavy metals content ( $\mathrm{Fe}, \mathrm{Mn}, \mathrm{Zn}, \mathrm{Cu}, \mathrm{Ni}, \mathrm{Cr}, \mathrm{Co}$ and $\mathrm{Pb}$ ) in the sediment of Lake Edku. Surface sediment samples were collected in September (summer) 2016. The metals content in the Lake sediments decreased in the order of $\mathrm{Fe}>\mathrm{Mn}>\mathrm{Cr}>\mathrm{Co}>\mathrm{Zn}>\mathrm{Cu}>\mathrm{Ni}=\mathrm{Pb}$. The range and average $\pm \mathrm{SD}$ concentrations $\left(\mu \mathrm{gg}^{-1}\right)$ of the investigated heavy metals were 30275-43312 (38822 \pm 4312$)$ for Fe; 781.8-3432 (1923.6 \pm 855$)$ for $\mathrm{Mn}$; 53.8-107 (82.5 \pm 18$)$ for $\mathrm{Zn}$; 55.2-91.5(72.3 \pm 13$)$ for $\mathrm{Cu}$;87.3-158.8(113.1 \pm 24$)$ for $\mathrm{Cr}$; 23.0-63.3(45.0 \pm 13.0$)$ for $\mathrm{Ni}$;

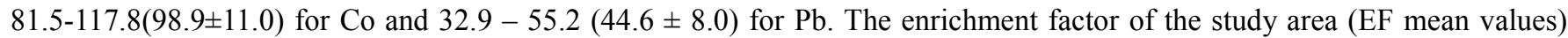
have the order of $\mathrm{EF}_{\mathrm{Co}}>\mathrm{EF}_{\mathrm{Mn}}>\mathrm{EF}_{\mathrm{Pb}}>\mathrm{EF}_{\mathrm{Cu}}>\mathrm{EF}_{\mathrm{Cr}}>\mathrm{EF}_{\mathrm{Zn}}>\mathrm{EF}_{\mathrm{Ni}}$. According to the geoaccumulation index (Igeo classification), the study area may be practically unpolluted with $\mathrm{Fe}, \mathrm{Zn}, \mathrm{Ni}$ and $\mathrm{Cr}$ (Igeo ranged from -2.15 to -0.41) along the study area. On the other hand, the Igeo of Co ranged from moderately to strongly pollutedarea. In addition, a lower degree of pollution was found in the sediments by the other heavy metals; $\mathrm{Pb}$ and $\mathrm{Cu}$ (unpolluted to moderate). The Pollution Load Index (PLI) indicated that station IX was characterized by low level of PLI with value of 1.25 while the other stations (ranged from 1.50 to 1.67).
\end{abstract}

Keywords: Sediment, Heavy Metals, Lake Edku, Enrichment Factor

\section{Introduction}

Lake Edku lies in the north of the Nile Delta, west of the Rosetta branch between Long. $30^{\circ} 8 \backslash 30 \backslash \backslash \& 30^{\circ} 23 \backslash 00 \backslash \mathrm{E}$ and Lat. $31^{\circ} 10 \backslash \& 31^{\circ} 18 \backslash \mathrm{N}$. It is one of four coastal deltaic lakes that are connected to the Mediterranean Sea. Its area has decreased from $28.5 \times 103$ to about $12 \times 103$ Feddans (is an area unit equals 4200 sq. meters) as a result of agricultural reclamation. The lake can be divided into three ill-defined basins; eastern, central and western. Lake Edku receives huge amounts of drainage water from three main drains, namely Berzik, Edku and El-Boussili, which open into the eastern basin of the lake [1]. The maximum inflow from all drains is recorded during summer, while the minimum is in winter. An amount of $3.3 \times 10^{6} \mathrm{~m}^{3}$ per day of brackish water is introduced into Abu Qir Bay from Lake Edku through Boughaz El-Maadiya [1, 3, 4, 5, 6, 7, 8, 9] have studied the hydrographic and chemical characteristics of Lake Edku water and sediments. Shata \& Okbah (2001) [10] studied the geochemical behavior of some trace elements of deep subsurface sediments of Lake Edku. Shata (2000) [11] observed the transport of carbonate granules to the subsurface sediments of Lake Edku from Abu Qir headline.

The present investigation aims to study the regional distribution of trace metals contamination in the surface 
sediment of Lake Edku and to evaluate pollution load index (PLI), enrichment factor (EF) as well as geoaccumulation index (Igeo) of the Lake sediments.

\section{Material and Methods}

\subsection{Study Area and Sampling Sites}

Ten stations were selected to cover the whole area of Lake Edku. Surface sediments samples were collected during September (summer) 2016. The sediment samples were collected once from all the selected stations. The positions of these stations are shown in Fig. 1.

\subsection{Analytical Methods of Sediments Analysis}

The sampling has been carried out by means of plastic tube (PVC), digging gently into the uppermost layer of the sediment. Samples from each site were divided into two subsamples, then homogenized by mixing and kept in clean plastic containers. Samples were stored frozen until analysis. A sub-sample was taken to determine chemical and physical characteristics of the sediments such as grain size distribution, total organic matter and calcium carbonate contents.

\subsubsection{Grain Size Analysis and Total Organic Carbon (TOC)}

About $25 \mathrm{gm}$ of dried samples was taken for mechanical analysis. The samples were subjected to the combined technique of dry sieving and pipette analysis [12]. Total organic carbon (TOC) was determined according to the method described by Gaudette and Flight [13]. This method utilizes exothermic heating and oxidation with potassium dichromate $\left(\mathrm{K}_{2} \mathrm{Cr}_{2} \mathrm{O}_{7}\right)$ and concentrated sulphuric acid $\left(\mathrm{H}_{2} \mathrm{SO}_{4}\right)$ of powdered sediment sample and the titration of the excess dichromate with ferrous ammonium sulphate solution using diphenylamine as indicator. The organic carbon is converted to organic matter by multiplying the organic carbon values by the factor of 1.8 .

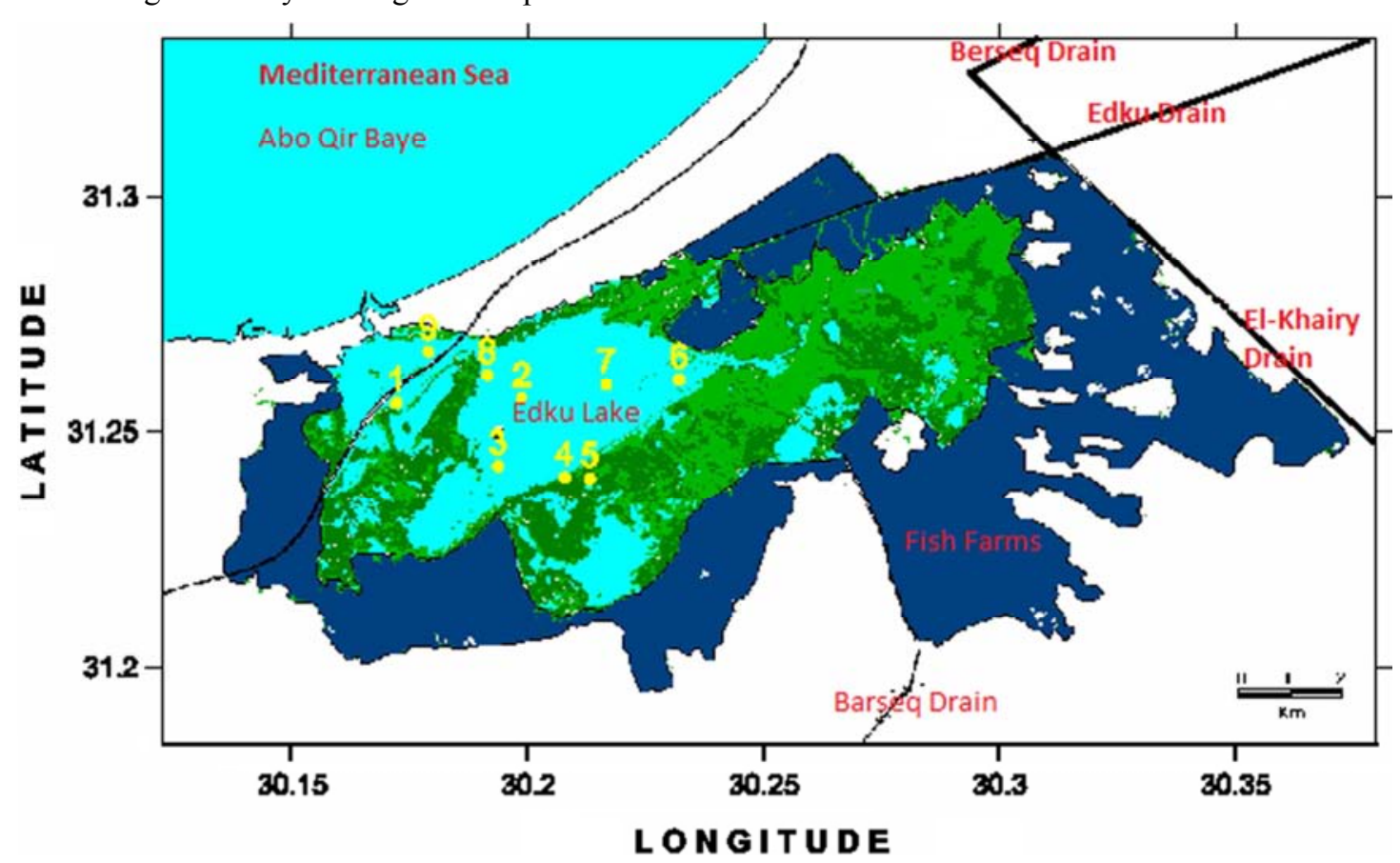

Figure 1. Lake Edku and sampling sites.

\subsubsection{Total Calcium Carbonate ( $\left.\mathrm{CaCO}_{3}\right)$}

The total carbonate was determined by titration technique described by Molina [14]. About $1 \mathrm{~g}$ of each sample was treated with $50 \mathrm{ml}$ standardized $0.5 \mathrm{~N} \mathrm{HCl}$ and then released amount of $\mathrm{CO}_{2}$ was determined by back titration with previously standardized $0.25 \mathrm{~N} \quad \mathrm{NaOH}$ solution using phenolphthalin indicator. The percentage of calcium carbonate $\left(\% \mathrm{CaCO}_{3}\right)$ was determined by the following equation:

$\mathrm{CaCO}_{3} \%=100 \times 0.05 \times\left\{\left(\mathrm{NHCl} \times \mathrm{V}_{\mathrm{HCl}}-(\mathrm{NNaOH} \times\right.\right.$ $\left.\left.\mathrm{V}_{\mathrm{NaOH}}\right)\right\}$

$\mathrm{NHCl}$ : Normality of standardized $\mathrm{HCl}, \mathrm{VHCl}$ : volume of standardized $\mathrm{HCl}$

$\mathrm{N}_{\mathrm{NaOH}}$ : Normality of standardized $\mathrm{NaOH}, \mathrm{V}_{\mathrm{NaOH}}$ : volume of standardized $\mathrm{NaOH}$

\subsubsection{Heavy Metal Analysis}

The total concentrations of heavy metals $(\mathrm{Cu}, \mathrm{Cd}, \mathrm{Fe}, \mathrm{Pb}$, $\mathrm{Zn}$ and $\mathrm{Mn}$ ) were determined according to Oregioni and Aston [15]. Nought point five gm of dried sample were digested using a mixture of nitric, perchloric and hydrofluoric acids in a previously cleaned and dried Teflon beaker, and then evaporated to near dryness at 80-C. After complete digestion, the residue was transferred to a $25 \mathrm{ml}$ volumetric flask with $0.1 \mathrm{M} \mathrm{HCl}$. The concentrations of different metals in the final extracts were measured using atomic absorption spectrophotometer in the flame mode (Shimadzu AA-6800). 


\section{Results and Discussions}

\subsection{Physicochemical Characterization of Lake Edku Sediments}

The distribution of calcium carbonate content in the studied sediments showed that the maximum carbonate content reached to $35.24 \%$ at station $\mathrm{X}$, which was covered with calcareous shells, and the minimum carbonate of $16.27 \%$ at station VIII. The average of carbonates in sediments of whole Lake Edku is $24.16 \%$. Organic matter was fluctuated between $3.06 \%$ and $8.11 \%$ In general, the high level of the total organic matter was found in the eastern region of the Lake, because there was a continuous in flow of wastewater, from main three drains namely Edku, Bousily and Berzik. The sand fraction dominated in the sediments of the western area of Lake Edku (average 47.7\%).

\subsection{Total Heavy Metals Distributions in Lake Edku Sediments}

Sediments are heterogeneous mixture of particles of different organic and inorganic components. Sediments represent one of the ultimate sinks for heavy metals discharged into the environment [16], they can absorb persistent and toxic chemicals levels many times higher than its concentration in water column $[17,18]$. Sediments play an important role in the transport and storage of potentially hazardous metals.

\subsubsection{Distribution of Total Concentration of Iron (Fe) and Manganese (Mn)}

Table 1 and Figure showed the distribution of total Fe concentrations in the sediments, it varied from 30275 to $43312 \mu \mathrm{gg}^{-1}$. The lowest content in the sediments (30275 $\left.\mu \mathrm{gg}^{-1}\right)$ was found at station IX, while the highest amount $\left(43312 \mu \mathrm{gg}^{-1}\right)$ was found at station $\mathrm{X}$. The average value was $\left(38822 \pm 4312{\mu \mathrm{gg}^{-1}}^{-1}\right.$. The result of the total Mn content in Lake Edku sediments ranged from $781.8-3432 \mu \mathrm{gg}^{-1}$. The lowest level of Mn was observed at station VI, while the highest value was recorded at station III, with an average value of $1923.6 \pm 855{\mu \mathrm{gg}^{-1}}^{-}$.

\subsubsection{Distribution of Total Concentration of Zinc (Zn) and Copper $(\mathrm{Cu})$}

In general, the concentrations of $\mathrm{Zn}$ in the eastern, and western areas of the lake (Table 1 )are higher than that of the median part, due to the effect of sea water entered to the lake at the west side, and the effect of drain water entered to the lake, in addition to industrial and agricultural activities along the eastern, and northern parts of the lake. The concentration of total $\mathrm{Zn}$ in our study was compared with the other value. It is clear that the average concentration of $\mathrm{Zn}\left(82.5 \pm 18.0 \mu \mathrm{gg}^{-}\right.$ ${ }^{1}$ ), found in the present study is higher than that reported in sediment of the lake at 2002. (Minimum value 59.3, maximum value 63.93) $\mu \mathrm{gg}^{-1}$ recorded by Masoud, (1987) [19]. Copper is generally introduced to the lake, as two main forms: the lithogenic and biogenic [20].

Lithogenic copper is essentially found incorporated in clay minerals. It is known that after decomposition of organic matter, the free copper may be adsorbed on the surface of clay minerals [20]. Metal pollutants also enter the environment from industrial mining effluent, combustion of fossil fuels, discharge of sewage sludge, fertilizer and pesticide residue. The concentrations of $\mathrm{Cu}$ in the present study are shown in Table 1. It ranged from 55.2-91.5 $\mu \mathrm{gg}^{-1}$. The lowest content was recorded at the station VI, while the high level was observed at the station VII, with an average value of $\left(72.3 \pm 13 \mu \mathrm{gg}^{-1}\right)$.

\subsubsection{Distribution of Total Concentration of $\mathrm{Cr}$, Ni Co and $\boldsymbol{P B}$}

The results of total $\mathrm{Cr}$, $\mathrm{Ni} \mathrm{Co}$ and $\mathrm{Pb}$ concentration in Lake Edku sediments are shown in Table 1. The range and average \pm SD concentrations $\left(\mu \mathrm{gg}^{-1}\right)$ were $87.3-158.8(113.1 \pm 24)$ for $\mathrm{Cr}$;

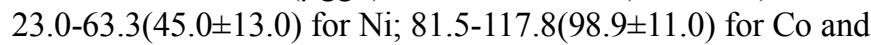
$32.9-55.2(44.6 \pm 8.0)$ for $\mathrm{Pb}$. The lowest content of $\mathrm{Cr}$ and $\mathrm{Ni}$ were recorded at station IX, while the high level was observed at the station VI, with average values of $113.1 \pm 24$ $\mu \mathrm{gg}^{-1}$ for $\mathrm{Cr}$ and $45.0 \pm 13.0$ for $\mathrm{Ni}$. The highest content of $\mathrm{Co}$ and $\mathrm{Pb}$ were observed at the station $\mathrm{X}$, with average values of 98.9.1 $\pm 11 \mu \mathrm{gg}^{-1}$ and 44.6.1 $\pm 8.0 \mu \mathrm{gg}^{-1}$, respectively.

\subsection{Assessment of Heavy Metal Pollution}

Importance of geochemical baseline natural and anthropogenic anomalies coexists in environmental geochemical research, so it is important to distinguish an anthropogenic anomaly from a natural anomaly for environmental impact assessment. All manmade chemical changes, regardless of their scale or origin, are superimposed upon a variable natural background. A geochemical baseline of trace elements provides the means to distinguish between the natural origin and the anthropogenic origin of the trace element in the environmental compartment [21], for example, Singh et al. (2003)[22] established baseline concentration of heavy metals to separate anthropogenic source from geogenic distribution.

Geochemical baselines are very important in environmental legislation, which prescribes limits for heavy metals in contaminated land and other surficial materials as defined by environmental authorities [24]. Baseline geochemical surveying is important as it can [25]: (1) help to determine the natural state of the environment; (2) support optimum mitigation strategies to help solve environmental problems; (3) increase understanding of immediate hazards; (4) help find possible mineral deposits; and (5) provide information on disease distribution when combined with epidemiological studies.

Geochemical baseline refers to the prevailing variation in the concentration of an element in the surficial environment [26]. However, the term Baseline concentration is defined as $95 \%$ of the expected ranges of metal concentration around a mean in a normal sample [27]. It represents the natural heavy metal content (background) in samples without human or urban influences in an idealized situation [22]. (c) According to [28], 'geochemical baselines' are concentrations of substances characterizing variability in the geochemistry of 
earth's surface materials and are needed for 'documenting the present state of the surface environment and to provide datum against which any changes can be measured'. (d) The term geochemical baseline concentration refers to an expected concentration range of an element around a mean in normal populations of sample concentrations [29]. (e) Geochemical baseline refers to the prevailing variation in the concentration of an element in the surficial environment [30].

Table 1. Concentration of some heavy metals $\left(\mathrm{mgkg}^{-1}\right)$ in Lake Edku sediments.

\begin{tabular}{|c|c|c|c|c|c|c|c|c|}
\hline Stations & $\mathrm{Fe}$ & Mn & $\mathbf{Z n}$ & $\mathrm{Cu}$ & $\mathrm{Cr}$ & $\mathbf{N i}$ & Co & $\mathbf{P b}$ \\
\hline $\mathrm{I}(1)$ & 43262 & 1170 & 107 & 64.5 & 123.3 & 58.8 & 96 & 47.51 \\
\hline $\mathrm{II}(2)$ & 38800 & 2151 & 79.5 & 78.3 & 94.8 & 44.3 & 94 & 52.3 \\
\hline III(3) & 38075 & 3432 & 77 & 55.9 & 104.3 & 48.5 & 94.3 & 39.8 \\
\hline IV(4) & 41425 & 2372 & 73.5 & 82 & 98.8 & 45.5 & 98.8 & 51.4 \\
\hline$V(5)$ & 39650 & 1744 & 83.5 & 73.6 & 99 & 43.3 & 101.3 & 38.2 \\
\hline $\mathrm{VI}(6)$ & 40550 & 781.8 & 100.5 & 55.2 & 158.8 & 63.3 & 93.5 & 41.9 \\
\hline VII(7) & 36775 & 1354 & 72.8 & 91.5 & 109.5 & 54.8 & 81.5 & 46.7 \\
\hline IX(9) & 30275 & 1975 & 53.8 & 61.3 & 87.3 & 23 & 100.5 & 40.8 \\
\hline$X(10)$ & 43312 & 1478.8 & 105 & 83.4 & 135 & 32.5 & 117.8 & 55.2 \\
\hline Min & 30275 & 781.8 & 53.8 & 55.2 & 87.3 & 23 & 81.5 & 32.9 \\
\hline Max & 43312 & 3432 & 107 & 91.5 & 158.8 & 63.3 & 117.8 & 55.2 \\
\hline Aver. & 38822.8 & 1923.6 & 82.5 & 72.3 & 113.1 & 45.0 & 98.9 & 44.6 \\
\hline$\pm \mathrm{SD}$ & 4312 & 855 & 18 & 13 & 24 & 13 & 11 & 8 \\
\hline Background Values & 46700 & 950 & 95 & 40 & 90 & 68 & 13 & 20 \\
\hline
\end{tabular}

Background Values [23]

Geochemical background is understood mainly as a natural value for a given medium not impacted by anthropogenic activities [31]. As no virgin ecosystem exists [30], it is impossible to determine the geochemical background. This gives rise to the concept of geochemical baseline, defined as the level of trace elements in soils that are not under the direct influence of humans. Therefore, the geochemical baseline would be the sum of the geochemical background plus a small quantity due to diffuse contamination [28, 30, 32, 33].

\subsubsection{The Geoaccumulation Index (Igeo)}

The geoaccumulation index (Igeo) was used to define the degree of anthropogenic pollution in the sediments. The index is the enrichment on geological substrates and can be calculated using the following equation [34].

$$
I_{\text {geo }}=\log _{2}\left\{\mathrm{C}_{\mathrm{n}} / 1.5 \times \mathrm{B}_{\mathrm{n}}\right\}
$$

Where $C_{n}$ is the measured concentration of the examined metal in sediments; $\mathrm{Bn}$ is the geochemical background concentration for the element $\mathrm{n}$ which is either directly measured in pre-civilization sediments of the area or taken from the literature (average shale value described by
Turekian and Wedepohl(1961) [23], and 1.5 is the correction factor for variation in background values due to lithogenic effects. The Igeo consists of seven grades, whereby the highest grade (6) reflects 100-fold enrichment above background values. Förstner et al. (1993) [34] listed geoaccumulation classes and the corresponding pollution intensity for different indices. The index has been applied by many researchers $[26,35,36]$ to distinguish heavy metal levels in anthropogenically enriched sediments from preindustrial or natural background levels in equivalent sediments. However, this index depends on the choice of an appropriate natural background value. Since there are no metal background values for this study area, the crustal average values [37] were used to calculate this index.

Igeo values were classified into seven grades: Igeo $\leq 0$ (grade 0),practically unpolluted; $0<$ Igeo $\leq 1$ (grade 1), unpolluted to moderate; $1<$ Igeo $\leq 2$ (grade 2), moderately polluted; $2<$ Igeo $\leq 3$ (grade 3 ), moderately to strongly polluted; $3<$ Igeo $\leq 4$ (grade 4 ), strongly polluted; $4<$ Igeo $\leq 5$ (grade 5), strongly to very strong polluted; Igeo $>5$ (grade 6), very strong polluted [34].

Table 2. Geoaccumulation index (Igeo values) for heavy metals of Lake Edku sediments.

\begin{tabular}{|c|c|c|c|c|c|c|c|c|}
\hline St & $\mathrm{Fe}$ & Mn & $\mathbf{Z n}$ & $\mathrm{Cu}$ & $\mathrm{Cr}$ & $\mathrm{Ni}$ & $\mathbf{P b}$ & Co \\
\hline 1 & -0.70 & -0.28 & -0.41 & 0.10 & -0.13 & -0.79 & 0.66 & 2.30 \\
\hline 2 & -0.85 & 0.59 & -0.84 & 0.38 & -0.51 & -1.20 & 0.80 & 2.27 \\
\hline 3 & -0.88 & 1.27 & -0.89 & -0.10 & -0.37 & -1.07 & 0.41 & 2.27 \\
\hline 4 & -0.76 & 0.74 & -0.96 & 0.45 & -0.45 & -1.16 & 0.78 & 2.34 \\
\hline 5 & -0.82 & 0.29 & -0.77 & 0.29 & -0.45 & -1.24 & 0.35 & 2.38 \\
\hline 6 & -0.79 & -0.87 & -0.50 & -0.12 & 0.23 & -0.69 & 0.48 & 2.26 \\
\hline 7 & -0.93 & -0.07 & -0.97 & 0.61 & -0.30 & -0.90 & 0.64 & 2.06 \\
\hline 9 & -1.21 & 0.47 & -1.41 & 0.03 & -0.63 & -2.15 & 0.44 & 2.37 \\
\hline 10 & -0.69 & 0.05 & -0.44 & 0.48 & 0.00 & -1.65 & 0.88 & 2.59 \\
\hline Min. & -1.21 & -0.87 & -1.41 & -0.12 & -0.63 & -2.15 & 0.13 & 2.06 \\
\hline Max. & -0.69 & 1.27 & -0.41 & 0.61 & 0.23 & -0.69 & 0.88 & 2.59 \\
\hline Aver. & -0.86 & 0.28 & -0.83 & 0.25 & -0.29 & -1.26 & 0.55 & 2.33 \\
\hline
\end{tabular}


The results of Igeo values of heavy metals are given in Table 2. According to the Igeo classification, the study area may be practically unpolluted with $\mathrm{Fe}, \mathrm{Zn}, \mathrm{Ni}$ and $\mathrm{Cr}$ (Igeo ranged from -2.15 to -0.41 ) along the study area. On the other hand, the Igeo of Co ranged from moderately to strongly polluted In addition, a lower degree of pollution was found in the sediments by the other heavy metals; $\mathrm{Pb}$ and $\mathrm{Cu}$ (unpolluted to moderate) while $\mathrm{Mn}$ statues revealed practically unpolluted to moderate at station I,VI and VII. There was no pollution with $\mathrm{Fe}$ in the sediments and could be neglected due to very low Igeo value obtained (Igeo ranged from -1.21 to -0.69$)$. In conclusion, the examined heavy metals in sediments of the study area showed wide ranges of concentrations due to spatial variations of metal distribution. The differences could be attributed to the sediment characteristics and land-based point and non-point inputs, especially from industrial activities. The Igeo showed that all heavy metals are in grade 0 and grade 2 (Table 2). This suggests that the sediments of Lake Edku are having background concentrations for all the studied metals except $\mathrm{Co}$, and these elements are practically unchanged by anthropogenic influences, while the concentration of $\mathrm{Co}$ exceeded the average shale value. This dangerous metal may be derived from industrial waste

The two approaches in evaluating heavy metal pollution, comparing with sediment quality guidelines and use of the geoaccumulation index gave quite similar information that the sediments were polluted with $\mathrm{Pb}$, but no categorization of the degree of pollution based on the former approach. In addition, the present study showed that anthropogenic activities for heavy metals contribution in the area were marked at minimal.

\subsubsection{Estimation of Enrichment Factor (EF)}

The extent of heavy metal contamination compared to the background area was assessed using the enrichment factor (EF), [38, 39] Enrichment factor is a good tool to differentiate the metal source between anthropogenic and naturally occurring [40] Metal concentrations were normalized to the textural characteristic of sediments with respect to $\mathrm{Fe}$. Iron was chosen as the element of normalization because natural sources $(1.5 \%)$ vastly dominate its input [41]. Iron was selected because it is a major sorbent phase for trace metals, and is a quasiconservative tracer of the natural metal-bearing phases in fluvial and coastal sediments $[42,43]$. The degree of modification in the chemical composition of sediments may be different at each sampling point due to different magnitude of source contributions at each station [44]

$$
\mathrm{EF}=\{(\text { Metal } / \mathrm{Fe}) \text { Sample }\} /\{(\text { Metal } / \mathrm{Fe}) \text { Crust }\}
$$

Where $\mathrm{EF}$ is the enrichment factor, $\left(\mathrm{M}_{\text {sample }} / \mathrm{Fe}_{\text {sample }}\right)$ is the ratio of metal and $\mathrm{Fe}$ concentration of the sample, and $(\mathrm{M}$ background / $\mathrm{Fe}$ background $)$ is the ratio of metal and $\mathrm{Fe}$ concentration of a background. The values for the surficial earth crust of $\mathrm{Fe}, \mathrm{Mn}, \mathrm{Cu}, \mathrm{Zn}, \mathrm{Ni}, \mathrm{Cr}, \mathrm{Co}$ and $\mathrm{Pb}$ were taken from Turekian and Wedepohl (1961) [23] represent the average composition of the average Shale materials (47200, $850,45,95,68,90,13$ and $20 \mu \mathrm{gg}^{-1}$, respectively.) Because of natural mineralogical differences of sediment and analytical uncertainty, only sediments with an EF greater than 2 were considered to be as enriched $[45,46]^{-}$Many authors prefer to express the metal contamination with respect to average shale to quantify the extent and degree of metal pollution [47]

The assessment criteria are based on the EF values. Generally EF values less than 10 are not considered significant, since such small enrichments may arise from differences in the composition of local soil material and reference soil used in EF calculations. An enrichment factor (EF) technique is used in the area of sediments [39, 48, 49].

Elements without enrichment $(\mathrm{EF}<10)$, elements with medium-level enrichment $(10<\mathrm{EF}<100)$ and finally highly enriched elements $(E F>100)$.

In the present study, the enrichment factor was used to assess the level of contamination and the possible anthropogenic impact in sediments of Lake Edku. To identify anomalous metal concentration, geochemical normalization of the heavy metals data to a conservative element, such as Fe was employed [50,51]. In this study iron has also used as a conservative tracer to differentiate natural from anthropogenic components.

Table 3 gives $\mathrm{EF}$ values of $\mathrm{Mn}, \mathrm{Cu}, \mathrm{Zn}, \mathrm{Ni}, \mathrm{Cr}, \mathrm{Co}$ and $\mathrm{Pb}$ Lake Edku sediments with the background concentrations of these metals. The results of Co revealed that the EF value ranged from 7.96 to 11.92 at all the sites; suggest that the sources are more likely to be anthropogenic. With some exception, the values of $\mathrm{EF}$ for $\mathrm{Mn}, \mathrm{Cu}, \mathrm{Zn}, \mathrm{Ni}, \mathrm{Cr}$ and $\mathrm{Pb}$ ranged between $<1.0$ and less than 4.0 were recorded in all of stations. For the study area $\mathrm{EF}$ mean values have the order of $\mathrm{EF}_{\mathrm{Co}}>\mathrm{EF}_{\mathrm{Mn}}>\mathrm{EF}_{\mathrm{Pb}}>\mathrm{EF}_{\mathrm{Cu}}>\mathrm{EF}_{\mathrm{Cr}}>\mathrm{EF}_{\mathrm{Zn}}>\mathrm{EF}_{\mathrm{Ni}}$ (Fig. 2 ). The difference in $\mathrm{EF}$ values may be due to the difference in the magnitude of input for each metal in the sediment and/or the difference in the removal rate of each metal from the sediments. The results of the present study show that Lake Edku sediments were highly enriched in Co.

Table 3. Enrichment factors (EF) for heavy metals of Lake Edku sediments.

\begin{tabular}{llllllll}
\hline Sites & Mn & Cu & Zn & Ni & Cr & Co & Pb \\
\hline I & 1.33 & 1.74 & 1.22 & 0.93 & 1.48 & 7.97 & 2.56 \\
II & 2.73 & 2.36 & 1.01 & 0.78 & 1.27 & 8.7 & 3.15 \\
III & 4.43 & 1.71 & 0.99 & 0.87 & 1.42 & 8.9 & 2.44 \\
IV & 2.81 & 2.31 & 0.87 & 0.75 & 1.24 & 8.57 & 2.9 \\
V & 2.16 & 2.17 & 1.04 & 0.75 & 1.3 & 9.18 & 2.25 \\
VI & 0.95 & 1.59 & 1.22 & 1.07 & 2.03 & 8.28 & 2.41 \\
VII & 1.81 & 2.9 & 0.97 & 1.02 & 1.55 & 7.96 & 2.97 \\
VIII & 2.95 & 2.19 & 0.94 & 0.68 & 1.29 & 9.84 & 1.91 \\
IX & 3.21 & 2.36 & 0.87 & 0.52 & 1.5 & 11.92 & 3.15 \\
X & 1.68 & 2.25 & 1.19 & 0.52 & 1.62 & 9.77 & 2.98 \\
Min & 0.95 & 1.59 & 0.87 & 0.52 & 1.24 & 7.96 & 1.91 \\
Max & 4.43 & 2.9 & 1.22 & 1.07 & 2.03 & 11.92 & 3.15 \\
Aver. & 2.45 & 2.17 & 1.03 & 0.79 & 1.50 & 9.25 & 2.65 \\
\hline
\end{tabular}




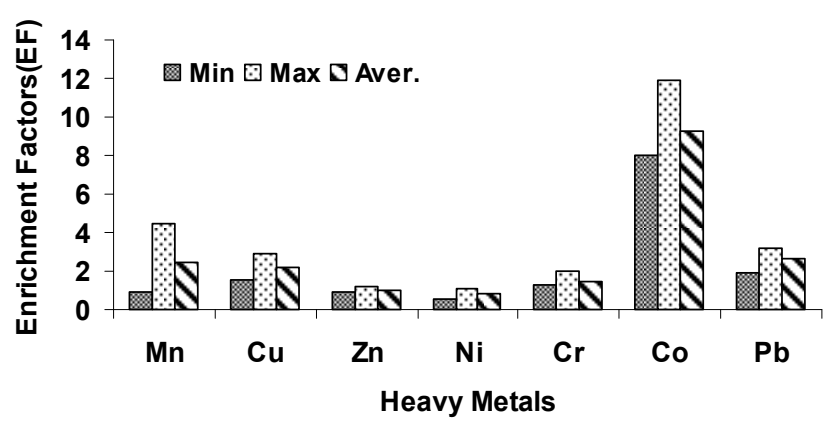

Figure 2. Min., Max. and Average of the Enrichment Factors (EF) for Heavy Metals of Lake Edku sediments.

\subsubsection{Contamination Factors $\left(C_{f}\right)$, Degree of \\ Contamination (Dc) and Pollution Load Index (PLI)}

Contamination factors of sediments have been widely used as environmental indicators and this ability to trace contamination sources and monitor contaminants is also well recognized. Thus, the accumulation of metals in the sediments is strongly controlled by the nature of the substrate as well as the physico-chemical conditions controlling dissolution and precipitation. The accumulation of heavy metals in sediments gives rise to two types of impacts on overlying water and both in a marine environment. The heavy metals themselves may have a synergistic or antagonistic effect on the environment. The level of contamination is expressed by the contamination factor (CF), $[52,53,54]$. This CF is the quotient obtained according to the following formula:

$$
\mathrm{CF}=\mathrm{C} \text { metal } / \mathrm{C} \text { background value. }
$$

Where $\mathrm{C}$ metal is the concentration of metal $\mathrm{n}$ expressed in $\mu \mathrm{g} \mathrm{g}^{-1}$ of dry weight, $\mathrm{C}$ background value represents the background level of the crust sediments [23].

According to Hökanson (1980) [52] the contamination factor, was classified into four groups; $\mathrm{CF}<1$ refers to the low contamination factor; $1 \leq \mathrm{CF}<3$ refers to the moderate contamination factor; $3 \leq \mathrm{CF}<6$ refers to the considerable contamination factors; $\mathrm{C}_{\mathrm{F}} \geq 6$ refers to the very high contamination factor.

The values of contamination factor (CF) are shown in Table 4. The results showed that most of the sites were considerable contamination for $\mathrm{Mn}, \mathrm{Cu}, \mathrm{Cr}$ and $\mathrm{Pb}$. On the other hand, the values of contamination factor revealed low levels for $\mathrm{Fe}, \mathrm{Zn}$ and $\mathrm{Ni}$ at all stations. The results revealed very high contamination factor $(\mathrm{CF}>6)$ for $\mathrm{Co}$.

From the contamination factor calculations, it was found that a regular monitoring for the concentrations of $\mathrm{Co}, \mathrm{Pb}$ and $\mathrm{Cu}$ is essential since their contamination factor at all the sampling sites exceeded the desirable limit for CF values and can cause potential pollution risk in the future. Degree of contamination (Dc) defined as the sum of all contamination factors for a given basin.

$$
\mathrm{Dc}=\Sigma \mathrm{C}_{\mathrm{f}} \text { (for } \mathrm{n} \text { of the metals) }
$$

For the description of the degree of contamination, degree the following terminologies have been used: Dc $<7$ low degree of contamination; $7 \leq \mathrm{Dc}<14$ moderate degree of contamination; $14 \leq \mathrm{Dc}<28$ considerable degree of contamination; Dc $\geq 28$ very high degree of contamination.

The degrees of contamination (Dc) values are found in Figure, Dc values indicate a considerable degree of contamination at the study area from suggesting serious anthropogenic pollution at all the stations from Station I to Station X.

The Pollution Load Index (PLI) is obtained as contamination Factors (CF). The PLI of the place are calculated by obtaining the n-root from the n- CFs that was obtained for all the metals. With the PLI obtained from each place [55]. In the present study PLI as developed by Tomlinson et al (1980) [56] was calculated as the following:

Table 4. Contamination Factor (CF)for heavy metals of of Lake Edku sediments.

\begin{tabular}{lllllllll}
\hline St & $\boldsymbol{C F}_{\boldsymbol{F e}}$ & $\mathbf{C F}_{\mathbf{M n}}$ & $\mathbf{C F}_{\mathbf{Z n}}$ & $\mathbf{C F}_{\mathbf{C u}}$ & $\mathbf{C F}_{\mathbf{C r}}$ & $\mathbf{C F}_{\mathbf{N i}}$ & $\mathbf{C F}_{\mathbf{P b}}$ & $\mathbf{C F}_{\mathbf{C o}}$ \\
\hline I & 0.93 & 1.23 & 1.13 & 1.61 & 1.37 & 0.86 & 2.38 & 7.38 \\
II & 0.83 & 2.26 & 0.84 & 1.96 & 1.05 & 0.65 & 2.62 & 7.23 \\
III & 0.82 & 3.61 & 0.81 & 1.4 & 1.16 & 0.71 & 1.99 & 7.25 \\
IV & 0.89 & 2.5 & 0.77 & 2.05 & 1.1 & 0.67 & 2.57 & 7.6 \\
V & 0.85 & 1.84 & 0.88 & 1.84 & 1.1 & 0.64 & 1.91 & 7.79 \\
VI & 0.87 & 0.82 & 1.06 & 1.38 & 1.76 & 0.93 & 2.1 & 7.19 \\
VII & 0.79 & 1.43 & 0.77 & 2.29 & 1.22 & 0.81 & 2.34 & 6.27 \\
VIII & 0.86 & 2.54 & 0.81 & 1.89 & 1.11 & 0.58 & 1.65 & 8.46 \\
IX & 0.65 & 2.08 & 0.57 & 1.53 & 0.97 & 0.34 & 2.04 & 7.73 \\
X & 0.93 & 1.56 & 1.11 & 2.09 & 1.5 & 0.48 & 2.76 & 9.06 \\
Min & 0.65 & 0.82 & 0.57 & 1.38 & 0.97 & 0.34 & 1.65 & 6.27 \\
Max & 0.93 & 3.61 & 1.13 & 2.29 & 1.76 & 0.93 & 2.76 & 9.06 \\
Aver. & 0.83 & 2.03 & 0.87 & 1.81 & 1.26 & 0.66 & 2.23 & 7.61 \\
\hline
\end{tabular}

$$
\mathrm{PLI}={ }^{\mathrm{n}} \sqrt{ }(\mathrm{CF} 1 \times \mathrm{CF} 2 \times \mathrm{CF} 3 \times \ldots \mathrm{CFn})
$$

Where, $\mathrm{CF}=$ contamination factor, $\mathrm{n}=$ number of metals, $\mathrm{C}$ metal $=$ metal concentration in polluted sediments, $\mathrm{C}$ Background value $=$ background value of that metal. The PLI value of $>1$ is polluted, whereas $<1$ indicates no pollution [57]. The world average concentration of Fe $(46700 \mu \mathrm{g} / \mathrm{g})$, Mn $(950 \mu \mathrm{g} / \mathrm{g}), \mathrm{Cu}(40 \mu \mathrm{g} / \mathrm{g}), \mathrm{Zn}(95 \mu \mathrm{g} / \mathrm{g}), \mathrm{Ni}(68 \mu \mathrm{g} / \mathrm{g}), \mathrm{Pb}$ $(20 \mu \mathrm{g} / \mathrm{g})$, and $\mathrm{Cr}(90 \mu \mathrm{g} / \mathrm{g})$ reported for shale were considered as the background value [23].

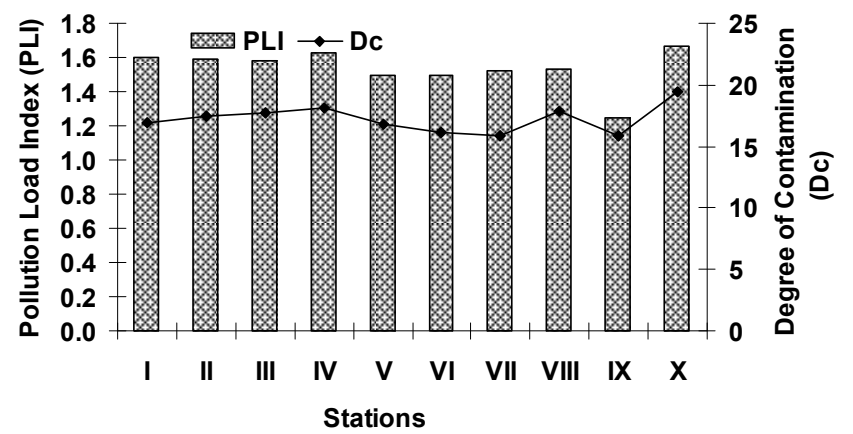

Figure 3. Pollution Load Index (PLI) and Degree of Contamination (Dc) for heavy metals of of Lake Edku sediments.

The Pollution Load Index (PLI) was calculated as shown in Figure. it can be indicated that station IX was characterized by 
low level of PLI with value of 1.25. This is low comparing with the other stations (ranged from 1.50 to 1.67 ).

\section{Conclusion}

The concentrations of $\mathrm{Fe}, \mathrm{Zn}$ and $\mathrm{Ni}$ in the all stations were equivalent or smaller of the background value, high amount of $\mathrm{Cu}$, increased two times than the background value. $\mathrm{Mn}$ increased from twice to three times than the background value. $\mathrm{Cr}$ similar to the background value except stations I, VI and $\mathrm{X}$ showed high content than the background value. Co was increased seven times while $\mathrm{Pb}$ increased two times comparing with those recorded in the background value in most of stations.

\section{References}

[1] Okbah M. A.; El-Gohary, S. El. (2002). Physical and Chemical Characteristics of Lake Edku Water, Egypt. Medit. Mar. Sci., 3/2, 27-39.

[2] Nessim, R. B.; EL-Deek, M. S. (1995). The influence of LandBased sources on the nutrients level in Abu- Qir. Bay. Journal of Bull. High Institute of public Health, Egypt. 25 (1): 209220

[3] Soliman, A. H. (1983). Quantitative and qualitative studies of the plankton of Lake Edku in relation to the local environmental conditions and to Fish food. M. Sc. Thesis, Fac. Sci. Alex. Univ., 220 pp.

[4] Saad, M. A. H. (1988). Studies on the core sediments of Lake Edku, Egypt. Rapp. Comm. Int. Mer. Medit., 31,2.

[5] Moussa, A. A.; EL-Sayed, M. A. (1990). Geochemistry of Fe, $\mathrm{Mn}, \mathrm{Zn}, \mathrm{Cu}, \mathrm{Pb}$ and $\mathrm{Cd}$ in sediment cores from Lake Edku. Rapp. Comm. Int. Mer. Medit., 32,1, 67.

[6] Shridah, M. M. A. (1992). recent observations on some hydrographic and chemical aspects of Lake Edku waters; Egypt. Bull. High Inst. Publ. Health, vol. XXII, (1): 185201.

[7] Abdel-Moati, A. R.; EL-Sammak, A. A. (1996). Man-made impact on the geochemistry of the Nile delta lakes. A study of metal concentrations in sediment. Journal of water, air and soil pollution, 90: 413-429.

[8] Shakweer, L. M., EL-Ebiary, E. H.; Zaki, M. A. (1998). Comparative study on the major biochemical constituents in the muscles of Mugil Cephalus inhabiting the Mediterranean water, the northern delta lakes and fish farms of Egypt. Bull. Nat. Ins. Oceanogr. Fish., Egypt. 24: 79-101.

[9] Nour EL-Din, N. M. (2000). Study of the chemical composition of suspended matter and adsorbed elements in Lake Edku. M. Sc. Thesis. Fac. Sci. Alex. Uni, 219 p.

[10] Shata, M. A. and Okbah, M. A. (2001). Geochemical Behavior of some trace elements in deep cores of Lake Edku, Egypt. 5 th Inter. Conf. On Geochemistry, Alex. Univ., Egypt, 12-13 Sept. 2001: 103-114.

[11] Shata, M. A. (2000). Lithofacies characteristics of subsurface sediments of Lake Edku, Egypt. (In Press).
[12] Folk, R. L. (1974). Petrography of sedimentary rocks. Univ. Texas, Hemphill, Austin, Tex., 182.

[13] Gaudette, H. E.; Flight. W. R. (1974). An inexpensive titration method for the determination of organic carbon in recent sediments. Journal of sedimentary petrology. 44 (1), 249-253.

[14] Molina, B. F. (1974). A rapid and accurate method for the analysis of calcium carbonate in small samples. J. Sed. Petrol., 44 (2): 589-590.

[15] Oregioni, B.; Aston. S. R. (1984). The determination of selected trace metals in marine sediments by flame atomic absorption spectrophotometry. IAEA Monaco Laboratory Internal Report. UNEP, reference methods for marine pollution studies, 38 .

[16] Bryan, G. W., Langston, W. J. (1992). "Bioavailability, accumulation and effects of heavy metals in sediments with special reference to United Kingdom estuaries," a review. Environmental Pollution 76: pp. 89-131.

[17] Yuan, C. G., J. B. Shi, B. He, J. F. Liu, L. N. Liang and G. B. Jiang, (2004). Speciation of heavy metals in marine sediments from the East China Sea by ICP-MS with sequential extraction. Environ. Int., 30: 769-783.

[18] Rodríguez-Barroso, R. M., Y. Benhamou, B. El Moumni, I. El Hatimi, J. L. García-Morales, (2009). Evaluation of metal contamination in sediments from north of Morocco: Geochemical and statistical approaches. Environ. Monit. Assess, 159 (1-4): 169-181.

[19] Massoud A. H. S. (1987). Limnological studies on the Nozha Hydrodrome, Egypt, with special reference to the problems of pollution Science of The Total Environment Volume 67, Issues 2-3, December 1987, Pages 195-214.

[20] Solomons, W., FÖrstner, U. (1984). Metals in the Hydrocycle. Springer Verlag, Berlin, p. 349.

[21] Baize D, Sterckeman T. (2001). Of the necessity of knowledge of the natural pedo geochemical background content in the evaluation of the contamination of soils by trace elements. Sci Total Environ 264: 127-139

[22] Singh M.; Muller G.; Sigh, I. B. (2003). Geogenic distribution and baseline concentration of heavy metals in sediments of the Ganges River, India. J Geochem Explor 80: 1-7.

[23] Turekian,K. K.; Wedepohl, K. H. (1961). Distribution of the elements in some major units of the earth's crust", American Geology Soc. Bulletin, 72: 175-182.

[24] van den Oever, F. (2000). Aruba-a geochemical baseline study. Neth J Geosci 79 (4): 467-477.

[25] Lech, M. E., Raymond, O. L., Wyborn, L. A. I. (2002). Potential applications in baseline geochemical data integration for geoscience Australia - a report of findings from a pilot study. Geoscience Australia, Record 2003/08, 35.

[26] Zhang, H. B., Luo, Y. M., Wong, M. H., Zhao, Q. G., Zhang, G. L. (2007). Defining the geochemical baseline: a case study of Hong Kong soils. Envron Geol 52: 843-851.

[27] Kabata-Pendias, A., Dudka, S., Chlopecha, A. (1992). Background levels and environmental influences on trace metals in soils of the temperate humid zone of Europe. In: Adriano DC (ed) Biogeochemistry of trace metals. CRC Press, Boca Raton, pp 61-84. 
[28] Darnley A. G. (1995). International geochemical mapping-a review. J Geochem Explor 55: 5-10.

[29] Chen M, Ma LQ, Harris WG (1999) Baseline concentration of 15 trace elements in Florida surface soils. J Environ Qual 28: $1173-1181$.

[30] Salminen R, Gregorauskiene V. (2000). Considerations regarding the definition of a geochemical baseline of elements in the surficial materials in areas differing in basic geology. Appl Geochem 15: 647-653.

[31] Gough L. P. (1993). Understanding our fragile environment lessons from geochemical studies. US Geol Surv Circ 1105: $1-34$.

[32] Tack FMG, Vanhaesebroeck T, Verloo MG, Van Rompaey K, VanRanst E. (2005). Mercury baseline levels in Flemish soils (Belgium). Environ Pollut 134: 173-179.

[33] Sierra M, Martı'nez FJ, Aguilar J. (2007). Baselines for trace elements and evaluation of environmental risk in soils of Almer1'a (SE Spain). Geoderma 139: 209-219.

[34] Förstner U, Ahlf W, Calmono W. (1993). Sediment quality objectives and criteria development in Germany. Water Science and Technology; 28: 307-16.

[35] Singh AK, Hasnain SI. (1999). Environmental geochemistry of Damodar River basin, east coast of India. Environmental Geology; 37: 124-36.

[36] Bakan G, Balkas TI. (1999). Enrichment of metals in the surface sediments of Sapanca Lake. Water Environment Research; 71: 71-74.

[37] Taylor SR. (1964). The abundance of chemical elements in the continental crust- a new table. Geochimica et Cosmochimica Acta; 28: 1273-85.

[38] Woitke, P.; Wellmitz, J.; Helm, D.; Kube, P.; Lepom, P., Litheraty, P. (2003). Analysis and assessment of heavy metal pollution in suspended solids and sediments of the river Danube. Chemosphere. 51: 633.642.

[39] Selvaraj, K.; Ram Mohan, V.; Szefer, P. (2004). Evaluation of metal contamination in coastal sediments of the Bay of Bengal, India: geochemical and statistical approaches. Mar. Pollut. Bull. 49: 174.185.

[40] Adamo, P.; Arienzo, M.; Imperato, M.; Naimo, D.; Nardi, G.; Stanzione, D. (2005). Distribution and partition of heavy metals in surface and sub-surface sediments of Naples city port. Chemosphere. 61: 800.809

[41] Tippie, V. K. (1984). An environmental characterization of Chesapeake bay and a frame work for action. In: Kennedy, V. (ed.) the Estuary as a Filter. Academic Press, New York, pp. 467-487.

[42] Schiff, K. C.; Weisberg, S. B. (1999). Iron as a reference element for determining trace metal enrichment in southern California coastal shelf sediments. Mar. Environ. Res. 48: 161. 176.

[43] Turner, A.; Millward, G. E. (2000). Particle dynamics and trace metal reactivity in estuarine plumes. Estuar. Coast. Shelf Sci. 50: 761.774 .

[44] Atgm, R. S., O. El-Agha, A. Zararsiz, A. Kocatas, H. Parlak;
Tuncel, G. (2000). Investigation of the sediment pollution in Izmir Bay: Trace elements. Spectrochimica Acta Part B., 55: $1151-116$

[45] Angelidis, M. O.,; Aloupi, M. (1997). Assessment of metal contamination in shallow coastal sediments around Mytilene, Greece. International Journal of Environmental Analytical Chemistry, 68 (2), 281-293.

[46] Liaghati, Tania; Cox, Malcolm E.; Preda, Micaela (2005). Distribution of $\mathrm{Fe}$ in waters and bottom sediments of a small estuarine catchment, Pumicestone Region, southeast Queensland, Australia. Science of the Total Environment 336 (1-3):pp. 243-254.

[47] Forstner, U., Muller, G., (1973). Heavy metal accumulation in river sediments: A response to environmental pollution. Geoforum 14/17, 53-61.

[48] Szefer, P., Glasby, G. P., Stuben, D., Kusak, A., Geldon, J., Berner, Z.,; Neumann, T., Warzocha, J. (1999). Distribution of selected heavy metals and rare earth elements in surficial sediments from the polish sector of the Vistula Lagoon. Chemosphere, vol. 39 (15), pp. 2785-2798.

[49] Obiajunwa, E. I., Pelemo, D. A., Owolabi, S. A., Fasasi, M. K.; Johnson- Fatokun, F. O. (2002). Characteristics of heavy metal pollutants of soils and sediments around a crude-oil production terminal using EDXRF. Nuclear Instruments and Methods in Physics Research, vol. 194 (B), pp. 61-64.

[50] Zabetoglou, K.; Voutsa, D.; Samara, C. (2002). Toxicity and heavy metal contamination of surficial sediments from the Bay of Thessaloniki (Northwestern Aegean Sea) Greece. Chemosphere. 49, 17-26.

[51] Mucha, A. P., Vasconcelos, M. T. S. D., Bordalo, A. A. (2003). Macro benthic community in the Doura Estuary: relations with trace metals and sediment characteristics. Environmental Pollution, vol. 121, pp. 169-180.

[52] Hökanson, L. (1980). An ecological risk index for aquatic pollution control. A sedimentological approach. Water Res. 14, 975-1001.

[53] Savvides C., Papadopoulos, A., Haralambous K. J.; Loizidou M.(1995). Sea sediment contaminated with heavy metals: metal speciation and removal. Water Science and Technology, 32, No. 9-10, 65-73.

[54] Pekey H., Karakas D., Ayberk S., Tolum L.; Bakoglu M. (2004). Ecological risk assessment using trace elements from surface sediments of Izmir Bay (Northeastern Marmara Sea) Turkey. Marine Pollution Bulletin 48: 946-953.

[55] Soares, H. M., Boaventura, R. A. R.; Esteves da Silva, J. (1999). Sediments as Monitors of Heavy Metal Contamination in the Ave River Basin (Portugal): Multivariate Analysis of Data", Environmental Pollution, Vol. 105,: 311-323.

[56] Tomlinson,D. L., Wilson, J. G., Harris, C. R.; Jeffney, D. W. (1980). Problems in the assessment of heavy metal levels in estuaries and the formation of a pollution index", Helgol. Wiss. Meeresunters, 33: 566-572.

[57] Harikumar,P. S. Nasir U. P.; Mujeebu Rahma, M. P. (2009). Distribution of heavy metals in the core sediments of a tropical wetland system, "International Journal. Environmental Science Technology, 6 (2): 225-232. 